\title{
Sosyal Medya Kullanım Motivasyonlarının Kişilik Özellikleri ve Yaşam Doyumu Açısından İncelenmesi
}

\author{
Şükran KARACA*
}

\begin{abstract}
$\ddot{O} Z$
Teknolojinin gelişmesiyle birlikte sosyal medya popüler hale gelmiş ve günlük hayatta yaygın olarak kullanılmaya başlanmıştır. Özellikle akillı telefon kullanımının artması ve internet bağlantısının iyileştirilmesi, sosyal medya kullanımını her geçen gün daha da arttırmıştır. Sosyal medya kullanicilarının kişilik özellikleri ve yaşamdan elde ettikleri doyumlar ile sosyal medya araçlarının seçimi, kullanım biçimleri ve sıklığı arasında ilişki vardır. Bu nedenle bu çalışma sosyal medya kullanım motivasyonlarının kişilik özellikleri ve yaşam doyumu açısından incelenmesi amacıyla yapılmıştır. Çalışma kapsamında 385 kişiden çevrimiçi anket tekniğiyle elde edilen veriler analiz edilmiştir. Araştırma sonucunda sosyal medya kullanıcılarının özellikle nevrotik kişilik özelliğinin sosyal medya kullanım motivasyonları ve yaşam doyumu üzerinde anlamlı etkisinin olduğu sonucuna ulaşılmıştır.
\end{abstract}

Anahtar Kelimeler: Sosyal Medya, Sosyal Medya Motivasyonları, Kişilik, Yaşam Doyumu JEL Sinıflandirmast: M30, M31

\section{Investigation of Social Media Use Motivations in Terms of Personality Traits and Life Satisfaction}

\begin{abstract}
With the development of technology, social media became popular and 1 widely used in daily life. Especially, the increase in the use of smart phones and the improvement of the internet connection has increased the use of social media day by day. There is a relationship between the personality traits and life satisfaction of social media users and the selection, usage and frequency of social media tools. Therefore, this study was carried out to examine social media usage motivations in terms of personality traits and life satisfaction. Within the scope of the study, data obtained from 385 people using the online survey technique were analyzed. As a result of the research, it was concluded that especially the neurotic personality trait of social media users had a significant effect on their motivation to use social media and life satisfaction.
\end{abstract}

Keywords: Social Media, Social Media Motivations, Personality, Life Satisfaction

JEL Classification: M30, M31

\section{GİRIŞ}

Sosyal medya siteleri, kullanıcıların herkese açık bir profil oluşturmasına, bilgi paylaşmalarına, içerik oluşturmalarına ve diğer kullanıcılarla bağlantı kurmasına olanak sağlayan çevrimiçi ortamlardır (INTECO, 2009). Bu ortamlar, mevcut sosyal ilişkileri sürdürmek, son haberlerini almak ve nispeten daha az çabayla büyük bir ağ elde etmek için önemli bir platform aracı olarak kabul edilmektedir (Ghaisani vd., 2017). Bireylerin çoğu sosyal medya aracılığılla

*Doç. Dr., Sivas Cumhuriyet Üniversitesi Turizm Fakültesi Turizm İşletmeciliği Bölümü, sukrankaraca@gmail.com, ORCID:0000-0002-0268-1810, Araştırma Makalesi 
sohbet, bloglar, fotoğraflar, videolar yükleme gibi birçok içerik üretmektedir (Van Dijck, 2009). Kişileri bu içeriği üretmeye motive eden unsurları bilmek önemlidir. Sosyal medya siteleri geniş bir popülerlik, yüksek yayılma ve artan sayıda özellik sergilemektedir. Bu özellikler dikkate alındığında, Kullanım ve Doyumlar yaklaşımı gibi teorik çerçeveler aracılığıyla sosyal medya kullanım motivasyonları araştırılmaktadır. Sosyal medya çalışmalarında kullanılan kullanım ve doyumlar yaklaşımı, insanların belirli bir medyayı kullanma nedenlerini ve motivasyonlarını bilmek amacıyla araştırma yapmak için ilk itici gücü sağlamaktadır (Jamal J., 2015). Ruggiero (2000), kullanım ve doyumlar yaklaşımlarının araştırmacıların sosyal medya analizi için dikkate alınacak arabuluculuk iletişiminin ve çeşitli değişkenlerin kullanımlarının önemini bilmelerine ve öğrenmelerine yardımcı olacağını vurgulamıştır.

Kişilik özellikleri, durum güncellemeleri, paylaşım yapma, fotoğraf ve video paylaşımı gibi faktörler sosyal medya siteleri kullanım davranışları ile yakından ilişkilidir (Ryan ve Xenos, 2011; Ong vd., 2011; Moore ve McElroy, 2012; Lee vd., 2014; Fullwood vd., 2014). Kişilerin sosyal medya sitelerindeki davranışlarının sebebini anlamak çok önemlidir (Li vd., 2019). Bireyler sosyal medyayı boş zamanları değerlendirme, sosyal etkileşim, bilgilenme ve eğlence gibi ihtiyaçları için kullanmaktadırlar (Quan-Haase ve Young, 2010). Belirli bir ortamdan aranan ve elde edilen doyumlar(motivasyonlar), bu ortamin kullanılmasını, sıklığını ve yoğunluğunu etkilemektedir. Sosyal medya kullanımı yoluyla edinilen doyumlar çok sayıda bireysel, sosyal, ekonomik, kültürel ve politik faktörle şekillenmektedir. Dolayısıyla daha düşük yaşam memnuniyeti ve daha yüksek yaşam memnuniyeti bireylerin sosyal medya kullanım motivasyonları ile ilişkilidir (Papacharissi ve Rubin, 2000).

İlgili literatüre bakıldığında sosyal medya kullanım motivasyonları ile ilgili birçok çalışmaya rastlanılmıştır. $\mathrm{Bu}$ çalışmalarda sosyal medya kullanım motivasyonları ile kişilik ve yaşam doyumu ayrı ayrı ele alınmış bu çalışmada ise diğer çalışmalardan farklı olarak bütüncül bir yaklaşım izlenerek sosyal medya kullanım motivasyonları hem kişilik hem de yaşam doyumu açısından incelenmiştir.

\section{KAVRAMSAL ÇERÇEVE}

\section{A. Sosyal Medya Kullanım Motivasyonları}

Sosyal medya genellikle "kullanıcılar tarafından oluşturulan içerikten değer elde ederek, kullanıcılar arasındaki etkileşimlerin algılanmasını kolaylaştıran, internet tabanlı, merkezden uzak ve kalıcı kitlesel iletişim kanalları" olarak tanımlanmaktadır (Carr ve Hayes, 2015). Başka bir deyişle, sosyal medya bireylerin sadece kendilerine kim olduğunu göstermek için profiller oluşturmadıkları, aynı zamanda kendi içeriklerini oluşturdukları, arkadaşlarının veya diğer kullanıcıların çevrimiçi içeriklerini görebildikleri ve onlarla etkileşime girebildikleri ortamlardır (Alhabash ve Ma, 2017).

Kullanım ve doyumlar teorik yaklaşımı, belirli bir medyanın kullanıcı motivasyonlarını ve doyumlarını değerlendirmek için geliştirilmiştir (Katz vd., 1973). Bu yaklaşımın dört ana varsayımı vardır: (i) medya kullanımı hedefe yönelik 
ya da motive edicidir, (ii) insanlar ihtiyaçları ve isteklerini karşılamak için medyayı kullanmaktadır, (iii) medya kullanımına aracılık eden sosyal ve psikolojik faktörler vardır ve (iv) medya kullanımı ve kişiler arası iletişim ilişkilidir (Rubin, 1993). Kullanım ve doyumlar yaklaşımına göre, medya kullanıcıları iki farklı şekilde doyuma ulaşmaktadırlar; istenen(aranan) doyumlar ve elde edilen doyumlar. İstenen(aranan) doyumlar, kullanıcıların medyayı kullanarak elde edecekleri tatminkarlık türlerine ilişkin beklentilerini ifade ederken, elde edilen doyumlar ise medya kullanımının karşıladığ i ihtiyaçları ifade etmektedir (Katz vd., 1973; Rubin, 1993).

En popüler ve yaygın olarak bilinen sosyal medya siteleri Facebook, Whatsapp, Twitter, Instagram, Snapchat, Youtube ve Google'dir (Alexa, 2020). Facebook en popüler ve en çok ziyaret edilen sosyal medya ağıdır (Alexa, 2020). Facebook, fotoğraf veya video paylaşma, yorum yapma, hikaye oluşturma, durum güncelleme, özel mesajlaşma, etiketleme ve canlı akışlar yayınlama gibi özelliklerini sürekli olarak geliştirmiştir (Junco, 2013). Whatsapp, standart mesajlaşmaya alternatif olarak geliştirilmiştir. Whatsapp sesli ve görüntülü aramayı ve metin, fotoğraf, video, belge ve konum gibi birçok farklı medya türünün gönderilmesini ve alınmasını desteklemekte ayrıca sosyal medya uygulamaları olarak hikayeler oluşturma olanağı sağlamaktadır (Whatsapp, 2020). Whatsapp ve diğer mesajlaşma uygulamaları, bireylerin temel iletişim ihtiyacını daha iyi karşılamasını ve daha kolay iletişim kurmayı kolaylaştırmaktadır (Karapanos vd., 2016). Dünyanın en popüler mikroblog sitelerinden biri olan Twitter, bilgi paylaşımı, sosyal etkileşim, bilgi arama, içerik ve yeni teknoloji memnuniyetleri vb. için kullanılmaktadır (Liu vd., 2010). Birçok ülkede önemli haber ve gelişmeleri yaymak ve takip etmek için yaygın olarak kullanılmaktadır (Zhao vd., 2011). Instagram, gençler ve genç yetişkinler arasındaki popülaritesindeki hızlı büyüme nedeniyle en hızlı büyüyen sosyal medya sitesidir (Alhabash ve Ma, 2017). Instagram, kullanıcıların fotoğraf çekmesine, filtrelemesine ve paylaşmasına ve daha sonra eklenen özelliklerle canlı yayın ve hikaye oluşturmaya izin vermektedir. Snapchat, kullanıcılarının fotoğraf veya kısa videolar göndermesine izin veren bir anlık mesajlaşma uygulamasıdır. Kullanıcılar gönderilen anlık görüntülerin ne kadar süreyle görüntülenebileceğini belirleyebilmekte ve 24 saat boyunca sınırsız sayıda hikaye oluşturabilmektedir (Alhabash ve Ma, 2017). YouTube, İnternet'te ziyaret edilen tüm web sitelerinin siralamasında ikinci siradadır (Alexa, 2020). Hem amatör hem de profesyonel çok geniş bir kitleye hizmet etmektedir (Xu vd., 2016). Kullanıc1ların derecelendirme, video yükleme, yorum yapma ve paylaşma gibi yöntemleri kullanarak siteyle etkileşime girmesini sağlamaktadır (Khan, 2017). Google tarafından işletilen bir sosyal medya sitesi olan Google+, içerik paylaşımına izin vermek için anında mesajlaşma, video konferans, gruplandırma ve benzer ilgi alanlarına sahip kişilerle etkileşim kurma olanağ1 sunan bir ağdır (Google+, 2020).

Sosyal medya kullanım motivasyon ve doyumlarını açıklamak için çeşitli çalışmalar yapılmıştır. Fullwood, Sheehan ve Nichollis (2009), sosyal paylaşım sitesi Myspace'de yaptıkları bir çalışmada sosyal medyayı kullanmak için üç temel 
neden olarak kendini ifade etme, izlenim yönetimi ve ilişki kurmayı belirtmişlerdir. Urista ve vd. (2009) yaptıkları çalışmada iki şekilde doyum bulmuştur: iletişim doyumu ve sosyal doyumlar. Cha (2010) sosyal medya kullanım siklı̆̆ının kişilerarası fayda, gizlilik kaygıları, algılanan kullanım kolaylığı ve yaş gibi boyutlara göre değerlendirilebileceğini bulmuştur. Livingstone (2010) çalışmasında facebook, twitter ve instragram gibi sosyal medyanın kullanıcının bireyselliğini ve başkalarıyla ilişkilerini sunmada önemli bir rol oynadığını ortaya koymuştur. Ayrıca, ergenlerin farklı sosyal medya kullanırken kimlik korumalarına gereken önemi verdiğini vurgulamışlardır. Whiting ve Williams (2013) sosyal medyayı kullanmak için on motivasyon belirlemişler: sosyal etkileşim, bilgi arama, zaman geçirme, eğlence, rahatlama, iletişimsel yarar, kolaylik sağlama, görüş bildirme, bilgi paylaşımı ve diğerleri hakkında gözetim veya bilgi. Jamal J. (2015) sosyal medyayı kullanmak için eğlence, bilgi arama, kişisel yarar ve rahatlığı temel motivasyon faktörleri olarak belirlemiştir.

\section{B. Beş Faktör Kişilik Kuramı}

Kişilik, sosyal medya kullanım motivasyonlarını ve doyumlarını etkileyen önemli bir bireysel fark olarak kabul edilmektedir (Rubin, 1993). Kişiliğgin ne olduğunu açıklamak için birçok kuram geliştirilmiştir. Bunlar arasında en çok bilinenleri psikoanalitik kuramlar, sosyo-psikolojik kuramlar ve treyt(özellik) kuramlarıdır (Tuncer vd., 1992). Pazarlamacılar, kişilik araştırmalarında en fazla treyt kuramını kullanmaktadırlar. Çünkü bu kuram pazarlama metodolojisiyle uyumludur ve kişiliği çeşitli özellikler vasıtasıyla tarif etmektedir (Tsai, 2003). Bu nedenle bu çalışmada beş faktör kişilik kuramı kullanılmıştır. Beş faktör kişilik boyutları nevrotiklik, dişa dönüklük, deneyime açıklık, uyumluluk(yumuşak başlılık) ve sorumluluktan (özdenetim) oluşmaktadır ve şu özelliklerle ilgilidir. İlk özellik olan Nevrotiklik, bir kişinin psikolojik sıkıntı yaşama eğilimini yansıtır ve yüksek düzeydeki özellikler tehdide duyarlılık ile ilişkilidir. İkinci özellik Dışadönüklük, bir kişinin sosyalleşme ve olumlu duyguları yaşama eğilimini yansıtır. Üçüncü özellik olan Deneyime Açıklık, bireyin alternatif yaklaşımları dikkate alma, entelektüel olarak meraklı olma ve sanatsal uğraşların tadını çıkarma istekliliğini temsil eder. Dördüncü özellik olarak Uyumluluk, güvenme, sempatik ve işbirliğine yatkınlığı yansıtan kişilerarası davranışın başka bir yönüdür. Beşinci boyut olan Sorumluluk ise, bir bireyin örgütlenme, gayretli ve titizlik derecesini yansitmaktadır (Ross vd., 2009).

Kişilik, bireyleri neyin motive ettiğinin bir tahmincisi olmaktadır. Farklı kişilik özelikleri, farklı amaçlarla sosyal medya kullanımı gerektirebilmektedir (Ross vd., 2009). En sık atıfta bulunulan kişilik özelliklerinin sınıflandırma modeli olarak beş faktörlü kişilik modeli sosyal medya sitelerindeki davranışlarla ilişkilendirilmiştir (Ross vd., 2009; Amichai-Hamburger ve Vinitzky, 2010; Gosling vd., 2011; Ryan ve Xenos, 2011; Seidman, 2012; Moore ve McElroy, 2012). Nevrotik sosyal medya kullanıcıları kendini ifşa etmeye daha fazla eğilimlidirler (Kuss ve Griffiths, 2011), başkalarının özçekimlerine verdiği tepkilerle daha fazla ilgilenirler (Choi vd., 2017), Facebook'ta daha fazla zaman geçirirler (Moore ve McElroy, 2012) ve sosyal medyaya daha pasif bir şekilde dahil 
olurlar (Ryan ve Xenos, 2011). Dışadönük bireyler sosyal medyayı yeni insanlarla tanışma, sosyalleşme, bilgilendirme ve eğitim için bir görev yönetimi aracı olarak kullanırlar (Horzum, 2016). Ayrıca daha fazla sayıda fotoğraf ve özçekim yayınlarlar (Kim ve Chock, 2017), daha fazla sayıda arkadaşlarına (AmichaiHamburger ve Vinitzky, 2010) daha fazla kendini ifşa etme eğilimindedirler (Misoch, 2015). Deneyimlere açı olan bireyler, sosyal medyayı sıklıkla kullanmakta ve daha çok bilgi paylaşımında bulunmak ve tavsiye vermek amaciyla iletişim kurmaktadırlar (Kalmus vd., 2011). Bu bireyler kendisini Facebook'ta (Horzum, 2016) daha popüler olarak göstermek ve özçekim yüklemek, başkalarının özçekimlerini beğenmek veya yorumlamak gibi etkileşimlere daha fazla girerler (Choi vd., 2017). Deneyimlere daha açı olan bireyler, sosyal medyada kendileri hakkında daha fazla bilgi paylaşırlar (Amichai-Hamburger ve Vinitzky, 2010). Uyumluluk özelliği yüksek olan bireyler başkaları tarafindan paylaşılan içeriğe beğeniler ve yorumlarla daha fazla katılır (Choi vd., 2017) ve profillerine daha çok arkadaş eklerler (Ross vd., 2009). Sorumluluk sahibi bireyler ise sosyal medyay daha çok haber ve bilgi için kullanırlar (Ryan ve Xenos, 2011).

Kişilik özelliklerinin internet ve sosyal medya kullanımı ile ilişkisini konu alan çalışmalar farklı kişilik özelliklerine sahip bireylerin, sosyal medya kullanımında hangi tatmin arayışları içerisinde olduğunu açıklamaktadır (Avcılar ve Külter Demirgüneş, 2016). Swickert vd. (2002)'ne göre nevrotizm ve online faaliyetleri eğlence amaçlı kullanma arasında negatif bir ilişki söz konusudur. Ayrica nevrotizmi yüksek olan bireylerin algılanan sosyal destek düzeylerinin en düşük olduğunu vurgulamışlardır. Landers ve Lounsbury'e (2006) göre, hem dişadönüklüğü hem de uyumluluğu düşük olan bireyler normal hayatta arkadaşlık kurma konusunda zorluk yaşamaktadırlar ve bu nedenle Facebook gibi bir sosyal medya sitelerinde ekleyecekleri daha az sayıda arkadaşa sahip olması muhtemeldir. Avcilar ve Külter Demirgüneş (2016), sorumluluğu yüksek bireylerin sosyal medya kullanımında daha çok başarı hırsı ve kendisini önemli görme isteği ile motive olduğunu, daha az sorumlu bireylerin daha çok sosyalleşme yönünde motive olduğunu ifade etmişlerdir. Swickert vd.(2002) ve Butt ve Phillips (2008) sorumluluk sahibi bireylerin sosyal medyadan kaçınma olasılıklarının daha yüksek olduğunu vurgulamışlardır.

\section{Yaşam Doyumu}

Mutluluk kelimesi, refahla aynı anlama gelen bir kavramdır ve bu kavramlar günlük hayatta birbirlerinin yerine kullanılmaktadır. Layard (2005), mutluluğu yaşamdan keyif almak ve harika hissetmek olarak tanımlamıştır. Yaşam doyumu (memnuniyeti) kişinin çevresinin olumlu ya da olumsuz olabileceği genel bir değerlendirmeyi yansıtmaktadır (Scheufele ve Shah, 2000). Araştırmacılar genellikle yaşam doyumunu kişisel memnuniyet olarak görmektedirler (Diener vd., 1985). Sosyal medya siteleri, sosyal, duygusal ve bilişsel gelişim için önemlidir (Doğan, 2016). İnsanlar kişisel bilgilerini yayınlayarak, fotoğraf paylaşarak, ilgi alanlarını belirterek sosyal etkileşime girmektedirler. Kahneman ve Krueger'in (2006) araştırmasına göre, yaşam doyumu kısmen kişinin sosyal bağlantılarıyla belirlenmektedir. Yaşam memnuniyeti kişinin arkadaşlarına (Leary ve Kowalski, 
1990), kişilerarası iletişime (Diener vd., 2009) ve kişinin aile üyelerinin mutluluğuna (Clorevd., 2001) bağlıdır. Bollen vd. (2011) ise, mutlu insanların sosyal medyada olumlu yazılar paylaştığını ve kendileri gibi mutlu insanları takip ettiklerini, mutsuz insanların da mutsuz insanları takip ettiklerini ifade etmişlerdir. Başka bir ifadeyle, herkes kendine benzeyen insanlarla iletişim kurmayı tercih etmektedir. Sonuç olarak, mutlu insanlar, mutlu fotoğrafları, olumlu duyguları paylaşma eğilimindedir ve bu paylaşım ve yorumlar bireylerin psikolojik refahını olumlu anlamda arttırmaktadır (Doğan, 2016).

Valkenburg vd. (2006), Facebook'a aktif olarak katılan insanların bağl1lık yaşamaları ve kendilerini daha mutlu hissetmelerinin daha olası olduğunu vurgulamışlardır. Obi (2014), Facebook'ta geçirilen süre ile mutluluk arasında pozitif bir ilişki olduğunu tespit etmiştir. Aynı şekilde Rae ve Lonborg (2015) üniversite öğrencilerine yönelik yaptıkları çalışmada, sosyal medya sitelerini kullanma ile mutluluk arasında pozitif bir ilişki olduğunu bulmuşlardır. TandocJr vd. (2015) tarafindan yapılan çalışmada ise, sosyal medya siteleri kullanımının yaşam doyum derecesini önemli ölçüde ve olumlu olarak etkilediği sonucuna ulaşılmıştır.

\section{ARAŞTIRMANIN YÖNTEMI}

Araştırmanın temel amacı sosyal medya kullanım motivasyonlarını kişilik ve yaşam doyumu açısından incelemektir. Araştırmanın örneklemini 17 yaşından büyük sosyal medya kullanıcıları oluşturmaktadır. Bu araştırma kapsamında Kasım-Aralık 2019 tarihleri arasında çevrimiçi anket tekniği ile veriler toplanmış ve 385 anket elde edilmiştir.

Araştırma için oluşturulan anket formu dört kısımdan oluşmaktadır. İlk kısımda Balcı ve Ayhan (2017) tarafından geliştirilen ve İçirgin (2018) tarafından güvenilirlik ve geçerliliği test edilmiş olan "Sosyal Medya Kullanım Alışkanlıkları ve Motivasyonları", ikinci kısımda Goldberg (1990) tarafından geliştirilen ve Sudak ve Zehir (2013) tarafindan güvenilirlik ve geçerliliği test edilmiş olan "Kişilik Ölçeğii”, üçüncü kısımda Diener vd. (1985) tarafindan geliştirilen ve Dağlı ve Baysal (2016) tarafından Türkçe'ye uyarlanan "Yaşam Doyumu Ölçeği" kullanılmıştır. Anketin dördüncü ve son kısmında ise demografik sorular yer almaktadir.

Araştırmanın amaçları doğrultusunda geliştirilen araştırma hipotezleri ise aşağıdaki gibidir:

$\mathbf{H}_{1}$ :Sosyal medya kullanıcılarının kişilik özelliklerinin sosyal kaçış motivasyonu üzerinde anlamlı bir etkisi vardır.

$\mathbf{H}_{2}$ :Sosyal medya kullanıcılarının kişilik özelliklerinin sosyal etkileşim motivasyonu üzerinde anlamlı bir etkisi vardır.

$\mathbf{H}_{3}$ :Sosyal medya kullanıcılarının kişilik özelliklerinin bilgilenme motivasyonu üzerinde anlamlı bir etkisi vardır.

$\mathbf{H}_{4}$ :Sosyal medya kullanıcılarının kişilik özelliklerinin boş zamanları değerlendirme motivasyonu üzerinde anlamlı bir etkisi vardır.

H$_{5}$ :Sosyal medya kullanıcılarının kişilik özelliklerinin ekonomik fayda motivasyonu üzerinde anlamlı bir etkisi vardır. 
$\mathbf{H}_{6}$ :Sosyal medya kullanıcılarının kişilik özelliklerinin eğlence motivasyonu üzerinde anlamlı bir etkisi vardır.

$\mathbf{H}_{7}$ :Sosyal medya kullanıcılarının kişilik özelliklerinin yaşam doyumu üzerinde anlamlı bir etkisi vardır.

$\mathbf{H}_{8 \text { : }}$ H8: Sosyal medya kullanım motivasyonlarının yaşam doyumu üzerinde anlamlı bir etkisi vardır.

Araştırma hipotezleri kapsamında kullanılacak olan yaklaşım nicel, araştırma yöntemi ise keşfedici ve yordayıcı korelasyonel araştırma desenleri şeklindedir.

\section{VERILERIN ANALIZİ VE BULGULAR}

\section{A. Katılımcıların Demografik Özellikleri}

Katılımcıların demografik özellikleri ile ilgili tanımlayıcı istatistiki bilgiler Tablo 1'de gösterilmiştir:

Tablo 1.Katılımcılara İlişkin Demografik Bilgiler

\begin{tabular}{|c|c|c|c|c|c|}
\hline Katılımcıların Cinsiyet Dağılımı & $\mathbf{f}$ & $\%$ & $\begin{array}{ll}\text { Katılımcıların } & \text { Medeni } \\
\text { Durum Dağılımı } & \\
\end{array}$ & $\mathbf{f}$ & $\%$ \\
\hline Kadın & 212 & 55,1 & Evli & 146 & 38 \\
\hline Erkek & 173 & 44,9 & Bekar & 239 & 62,1 \\
\hline Toplam & 385 & 100 & Toplam & 385 & 100 \\
\hline Katılımcıların Yaş Dağılımı & $\mathbf{f}$ & $\%$ & $\begin{array}{l}\text { Katılımcıların Eğitim } \\
\text { Dağılımı }\end{array}$ & $\mathbf{f}$ & $\%$ \\
\hline $17-25$ & 180 & 46,8 & İlköğretim/Ortaöğretim & 32 & 8,4 \\
\hline $26-34$ & 85 & 22,1 & Lise & 45 & 11,7 \\
\hline $35-43$ & 78 & 20,3 & Önlisans & 38 & 9,9 \\
\hline 44 yaş ve üzeri & 42 & 10,9 & Lisans & 180 & 46,8 \\
\hline Toplam & 385 & 100 & Lisansüstü & 90 & 23,4 \\
\hline Katılımcıların Meslek Dağılımı & f & $\%$ & Toplam & 385 & 100 \\
\hline Kamu Sektörü Çalışanı & 103 & 26,8 & $\begin{array}{l}\text { Katılımcıların } \\
\text { Dağılımı }\end{array}$ & f & $\%$ \\
\hline Ev Hanımı & 26 & 6,8 & 2020 TL ve altı & 139 & 36,1 \\
\hline Özel Sektör Çalışanı & 85 & 22,1 & $2021-4000 \mathrm{TL}$ & 60 & 15,6 \\
\hline Öğrenci & 107 & 27,8 & $4001-6000 \mathrm{TL}$ & 55 & 14,3 \\
\hline İşsiz & 39 & 10,1 & $6001-8000 \mathrm{TL}$ & 45 & 11,7 \\
\hline Diğer & 20 & 5,2 & 8001 TL ve üzeri & 86 & 22,3 \\
\hline Toplam & 385 & 100 & Toplam & 385 & 100 \\
\hline
\end{tabular}

Tablo 1'e göre araştırmaya katılanların \%55,1'i kadın \%44,9'u erkektir. Kat1lımc1ların \%38'i evli \%62,1'i bekar; \%46,8'i, 17-25, \%22,1'i 26-34, \%20,3'ü $35-43$ ve $\% 10,9$ 'u 44 yaş ve üzeridir. Eğitim dağılımına bakıldığında $\% 46,8$ 'i lisans, \%23,4'ü lisansüstü, \%11,7'si lise mezunudur. Katılımciların meslek/meşguliyet dağılımına bakıldığına \%27,8'i öğrenci, \%26,8'i kamu sektörü çalışanı, \%22,1'i özel sektör çalışanı, \%10,1'i işsiz, \%6,8'i ev hanımı ve \%5,2'si diğer meslek gruplarında yer almaktadır. Son olarak katılımciların gelirlerine bak1ldığında ise, \%36,1'i 2020 TL ve altı, \%22,3'ü 8001 TL ve üstü, \%15,6's1 2021-4000 TL aras1, \%14,3'ü 4001-6000 TL aras1 ve \%44,7'si 6001-8000 TL arasinda bir gelire sahiptir.

\section{B. Açıklayıcı Faktör Analizi}

Araştırma kapsamında kullanılan "Kişilik", "Sosyal Medya Kullanım Alışkanlıkları ve Motivasyonları" ve "Yaşam Doyumu" ölçeklerine ilişkin açıklayıcı faktör analizi sonuçları aşağıda gösterilmiştir: 
Tablo 2. Kişilik Ölçeğine İlişkin Açıklayıcı Faktör Analizi

\begin{tabular}{|c|c|c|c|}
\hline Kişilik Ölçeği & $\begin{array}{l}\text { Faktör } \\
\text { Yükleri }\end{array}$ & $\begin{array}{c}\text { Kümülatif } \\
\text { Varyans(\%) }\end{array}$ & $\begin{array}{c}\text { Cronbach } \\
\text { Alpha }\end{array}$ \\
\hline 1.Uyumluluk & & 16,985 & ,887 \\
\hline Çevremdeki insanlarla ilgilenirim & ,768 & & \\
\hline Başkalarının duygularını, sıkıntılarını anlarım & ,738 & & \\
\hline $\begin{array}{l}\text { Arkadaş toplantılarında çok sayıda farklı insanla } \\
\text { sohbet ederim }\end{array}$ & ,718 & & \\
\hline Çevremdeki insanlara zaman ayırırım & ,715 & & \\
\hline İnsanlar benim yanımda kendilerini rahat hisseder & ,707 & & \\
\hline Başkalarının dertlerini, sıkıntılarını paylaşırım & ,682 & & \\
\hline Yufka yürekli bir insanım & ,638 & & \\
\hline Toplum içerisinde kendimi çok rahat hissederim. & ,503 & & \\
\hline 2.Nevrotiklik (Duygusal Denge) & & 33,601 & ,921 \\
\hline S1k sık üzülürüm & ,862 & & \\
\hline Olaylar beni çok derinden etkiler, çabuk yıkılırım &, 830 & & \\
\hline Kolay strese girerim & ,826 & & \\
\hline Hemen her şeye üzülürüm & ,815 & & \\
\hline Ruh halimi çok şey etkiler & ,802 & & \\
\hline Çok çabuk telaşlanırım & ,782 & & \\
\hline Ruh hali çok sık değişen biriyim & ,726 & & \\
\hline 3.Deneyime Açıklık & & 46,277 & ,893 \\
\hline Olayları anlayıp kavramada hızlıyımdır & ,812 & & \\
\hline Zengin bir kelime dağarcı̆̆ım var & ,770 & & \\
\hline Kültürlü bir insanım & ,759 & & \\
\hline Kusurları, eksiklikleri görebilirim & ,705 & & \\
\hline Zengin bir hayal gücüm var & 687 & & \\
\hline 4. Dışa Dönüklük & & 54,349 & ,638 \\
\hline Geri planda olmayı tercih ederim & ,731 & & \\
\hline Yabancıların arasında fazla konuşmam. & ,705 & & \\
\hline Dikkat çekici olmaktan hoşlanmam & ,546 & & \\
\hline Sohbetleri hep ben başlatırım & ,509 & & \\
\hline Dikkat çekmekten rahatsız olmam & ,499 & & \\
\hline Çevremdekilerle çok az şey paylaşırım. & 430 & & \\
\hline 5.Sorumluluk & & 62,165 & ,729 \\
\hline Çok dağınık bir insanım & ,824 & & \\
\hline $\begin{array}{l}\text { Genellikle aldığım şeyleri yerine koymayı } \\
\text { unuturum }\end{array}$ & ,712 & & \\
\hline Düzeni, düzenli olmayı severim & ,707 & & \\
\hline Programlı çalışırım & ,613 & & \\
\hline \multicolumn{4}{|c|}{$\begin{array}{l}\text { KMO:,878 Barlett Test:6980,543 Öz Değer: 1'den Fazla } \\
\text { Cronbach Alpha: } 841\end{array}$} \\
\hline
\end{tabular}

50 sorudan oluşan kişilik ölçeğine yapılan faktör analizi sonucunda, faktör yüklenimi 0,40 ’ın altında kalan ve faktör yapısını bozan ifadeler çıkarıldıktan sonra 30 ifade üzerinden analizler gerçekleştirilmiştir. Açıklayıcı faktör analizi sonucunda beş boyut elde edilmiş ve bu boyutların toplam varyansı açıklama oranı \%62,165'tir. Ayrica Cronbach Alpha değeri 0,841 olarak bulunmuş ve ölçeğin güvenilir olduğu sonucuna ulaşılmıştır. 
Tablo 3. Sosyal Medya Kullanım Alışkanlıkları ve Motivasyonları

Ölçeğine İlișkin Açıklayıcı Faktör Analizi

\begin{tabular}{|c|c|c|c|}
\hline $\begin{array}{l}\text { Sosyal Medya Kullanım Alışkanlıkları ve } \\
\text { Motivasyonları Ölçeği }\end{array}$ & $\begin{array}{l}\text { Faktör } \\
\text { Yükleri }\end{array}$ & $\begin{array}{c}\text { Kümülatif } \\
\text { Varyans(\%) }\end{array}$ & $\begin{array}{c}\text { Cronbach } \\
\text { Alpha }\end{array}$ \\
\hline 1.Sosyal Kaçış Motivasyonu & & 16,413 & 0,908 \\
\hline Sosyal medya kullanmak bana heyecan veriyor & ,802 & & \\
\hline Başkalarıyla nasıl anlaşabileceğimi gösterdiği için & ,746 & & \\
\hline İçimdeki duygu ve heyecanları açığa çıkardığı için & ,737 & & \\
\hline Bir gruba aitmiș duygusu hissedebilmek için & ,727 & & \\
\hline Bir an olsun problemlerimden uzaklaşmak için & ,727 & & \\
\hline Beni başka bir dünyaya götürdüğü için & ,715 & & \\
\hline $\begin{array}{l}\text { Ev, okul ve arkadaş çevremdeki dertlerimi } \\
\text { unutturuyor }\end{array}$ & ,695 & & \\
\hline Arkadaş bulmak, yeni insanlarla tanışmak için & ,664 & & \\
\hline Kendimi daha az yalnız hissetmemi sağladığı için & ,596 & & \\
\hline Beni sıkan insanlardan kurtulmamı sağladığı için & ,586 & & \\
\hline Dinlenmeme yardımcı olduğu için & ,582 & & \\
\hline Kafamı boşaltmaya yardımcı olduğu için &, 515 & & \\
\hline $\begin{array}{l}\text { Konuşacak birisi olmadığında bana arkadaşlık } \\
\text { ediyor }\end{array}$ & ,405 & & \\
\hline 2.Sosyal Etkileșim Motivasyonu & & 28,241 & $\mathbf{0 , 9 2 3}$ \\
\hline $\begin{array}{l}\text { Başkalarına görüş bildirmek ve tavsiyelerde } \\
\text { bulunmak için }\end{array}$ & ,800 & & \\
\hline $\begin{array}{l}\text { Edindiğim bilgiler hakkında başkalarıyla iletişim } \\
\text { kurabilmek için }\end{array}$ & ,797 & & \\
\hline $\begin{array}{l}\text { Diğer insanlarla bilgi paylaşımında bulunabildiğim } \\
\text { için }\end{array}$ & ,792 & & \\
\hline Ailem ve dostlarımla iletişimde bulunmak için & ,754 & & \\
\hline Tanıdığım insanlarla iletişiminde bulunmak için & ,736 & & \\
\hline Başkalarından destek almak için & 633 & & \\
\hline $\begin{array}{l}\text { Sosyal medyayı her zaman ve her yerde } \\
\text { kullanabildiğim için }\end{array}$ &, 575 & & \\
\hline 3.Bilgilenme Motivasyonu & & $\mathbf{3 8 , 6 3 0}$ & $\mathbf{0 , 8 4 7}$ \\
\hline Güvenilir bir haber kaynağı olduğu için & ,738 & & \\
\hline $\begin{array}{l}\text { Pek çok konuyu diğer medyada yer almadan önce } \\
\text { öğrendiğim için }\end{array}$ & ,722 & & \\
\hline $\begin{array}{l}\text { Dünyada ve Türkiye'de meydana gelen olayları } \\
\text { anında öğrenmek }\end{array}$ & ,706 & & \\
\hline $\begin{array}{l}\text { Üniversitemdeki gelişme/ aktiviteler hakkında bilgi } \\
\text { sahibi olmak }\end{array}$ & ,701 & & \\
\hline $\begin{array}{l}\text { Yaşadığım yöredeki gelişmeler ve etkinlikleri takip } \\
\text { etmek için }\end{array}$ & 649 & & \\
\hline $\begin{array}{l}\text { Bir konuda fikir sahibi olmama yardımcı olduğu } \\
\text { için }\end{array}$ & ,610 & & \\
\hline $\begin{array}{l}\text { Başka bir yerde ulaşamadığım bilgilere ulaşmak } \\
\text { için }\end{array}$ &, 547 & & \\
\hline 4. Boș Zamanları Değerlendirme Motivasyonu & & 48,199 & $\mathbf{0 , 8 8 4}$ \\
\hline Sosyal medya kullanmak zevkli &, 825 & & \\
\hline Sosyal medyayı seviyorum & ,768 & & \\
\hline $\begin{array}{l}\text { Boş zamanımı değerlendirmede bana çeşitli } \\
\text { alternatifler sunuyor }\end{array}$ & ,740 & & \\
\hline Sıkıldığımda vakit geçirmek için & ,735 & & \\
\hline İlginç şeyler bulmak için &, 556 & & \\
\hline 5.Ekonomik Fayda Motivasyonu & & $\mathbf{5 5 , 8 0 5}$ & $\mathbf{0 , 8 6 3}$ \\
\hline $\begin{array}{l}\text { Sosyal medyadan alışveriş etmenin kolaylığını/ } \\
\text { uygunluğunu seviyorum }\end{array}$ & ,803 & & \\
\hline $\begin{array}{l}\text { Ürün ve hizmetlerin indirimli olanlarını bulmak } \\
\text { için }\end{array}$ & ,799 & & \\
\hline
\end{tabular}




\begin{tabular}{|c|c|c|c|}
\hline $\begin{array}{l}\text { Ürün ve hizmetler hakkında yararlı bilgiler } \\
\text { edinmek için }\end{array}$ & ,788 & & \\
\hline Karlı mali bilgiler elde etmek için & ,587 & & \\
\hline 6. Eğlence Motivasyonu & & 61,734 & $\mathbf{0 , 8 2 4}$ \\
\hline Oyun oynamak için & 819 & & \\
\hline Sosyal medya eğlence ihtiyacımı karşılıyor & ,768 & & \\
\hline $\begin{array}{l}\text { Çeşitli müzik parçası dinlemek ve MP3 vb. } \\
\text { download etmek için }\end{array}$ & 669 & & \\
\hline $\begin{array}{l}\text { KMO:,934 Barlett Test:9065,985 } \\
\text { Cronbach Alpha:0,945 }\end{array}$ & \multicolumn{3}{|c|}{ Öz Değer: 1'den Fazla } \\
\hline
\end{tabular}

Sosyal medya kullanım alışkanlıkları ve motivasyonları ölçeğine yönelik yapılan açıklayıcı faktör analizi sonucunda 3 ifade faktör yapısını bozduğu için çıkarılmış ve 39 ifade üzerinden analizler gerçekleştirilmiştir. Açıklayıcı faktör analizi sonucunda altı boyut elde edilmiş ve elde edilen boyutların toplam varyansı açıklama oranı \%61,734'tür. KMO değeri 0,934 olarak tespit edilmiş ve bu oran örneklem büyüklüğünün faktör analizine uygun olduğunu göstermektedir. Ayrıca Cronbach Alpha değeri 0,945 olarak bulunmuş ve ölçeğin oldukça güvenilir olduğu sonucuna ulaşılmıştır.

Tablo 4, yaşam doyumu ölçeğine ilişkin açıklayıcı faktör analizi sonuçlarını göstermektedir.

Tablo 4. Yaşam Doyumu Ölçeğine İlişkin Açıklayıcı Faktör Analizi

\begin{tabular}{|c|c|c|}
\hline Yaşam Doyumu Ölçeği & $\begin{array}{l}\text { Faktör } \\
\text { Yükleri }\end{array}$ & $\frac{\text { Kümülatif Varyans }(\%)}{67,886}$ \\
\hline Yaşamımdan memnunum. &, 856 & \\
\hline Yaşam koşullarım mükemmeldir. &, 856 & \\
\hline Şimdiye kadar yaşamdan istediğim önemli șeylere sahip oldum. & 851 & \\
\hline İdeallerime yakın bir yaşantım vardır. & ,813 & \\
\hline $\begin{array}{l}\text { Tekrar dünyaya gelsem hayatımdaki hemen hemen hiçbir şeyi } \\
\text { değiştirmezdim }\end{array}$ & ,738 & \\
\hline $\begin{array}{ll}\text { KMO:,840 } & \text { Barlett Test:1004,721 } \\
\text { Cronbach Alpha:,877 } & \end{array}$ & Fazla & Anlamlilık: 0.000 \\
\hline
\end{tabular}

Yaşam doyumu ölçeğine ilişkin yapılan açıklayıcı faktör analizi sonucunda tek boyut elde edilmiştir. Elde edilen boyutun toplam varyansı açılama oranı $\% 67,886$ ve KMO değeri 0,840 tespit edilmiştir. Ölçeğin Cronbach Alpha değeri ise 0,877 olarak bulunmuştur.

\section{Normal Dağılıma İliş̧kin Bulgular}

Araştırmada kullanılacak analiz tekniklerini belirlemek amacıyla veriler normallik sınamasına tabi tutulmuştur. Yapılan Kolmogorov-Smirnov testinde verilerin normal dağılmadığı görülmüştür $(\mathrm{p}<0.05)$. Bu durumda faktörlerin ve maddelerin basıklık ve çarpıklık değerlerine bakılmıştır. Faktörlere ilişkin tanımlayıcı istatistikler aşağıdaki Tablo 5 'te verilmiştir.

Tablo 5. Faktör Puanlarına Ait Tanımlayıcı İstatistikler

\begin{tabular}{|l|c|c|c|c|c|c|c|}
\hline \multicolumn{1}{|c|}{ Faktörler } & N & Ort. & Ss. & Carpıklık & Basıklık & Min & Maks \\
\hline $\begin{array}{l}\text { Sosyal Kaçış } \\
\text { Motivasyonu }\end{array}$ & 385 & 3,3107 &, 79468 & $, 1,157$ & $-, 1,120$ & 1,38 & 4,92 \\
\hline $\begin{array}{l}\text { Sosyal Etkileşim } \\
\text { Motivasyonu }\end{array}$ & 385 & 3,6568 &, 90634 & $-1,621$ & $-0,298$ & 1,00 & 5,00 \\
\hline $\begin{array}{l}\text { Bilgilenme } \\
\text { Motivasyonu }\end{array}$ & 385 & 3,5978 &, 83985 & 0,377 & $-1,203$ & 1,14 & 5,00 \\
\hline
\end{tabular}




\begin{tabular}{|l|c|c|c|c|c|c|c|}
\hline $\begin{array}{l}\text { Boş Zamanları } \\
\text { Değerlendirme } \\
\text { Motivasyonu }\end{array}$ & 385 & 3,7844 &, 88221 & $-1,540$ & $-0,346$ & 1,00 & 5,00 \\
\hline $\begin{array}{l}\text { Ekonomik Fayda } \\
\text { Motivasyonu }\end{array}$ & 385 & 3,5474 & 1,00997 & $-1,447$ & 0,549 & 1,00 & 5,00 \\
\hline $\begin{array}{l}\text { Eğlence } \\
\text { Motivasyonu }\end{array}$ & 385 & 3,5022 & 1,08390 & $-1,431$ & 0,508 & 1,00 & 5,00 \\
\hline Uyumluluk & 385 & 3,8698 &, 75759 & $-1,793$ & 0,203 & 1,00 & 5,00 \\
\hline Nevrotiklik & 385 & 3,0961 & 1,03753 & $-1,862$ & 0,206 & 1,00 & 5,00 \\
\hline Deneyime Açıklık & 385 & 3,7018 &, 86916 & $-1,510$ & 0,481 & 1,00 & 5,00 \\
\hline Dişa Dönüklük & 385 & 2,8974 &, 69831 & $-1,269$ & $-0,191$ & 1,00 & 5,00 \\
\hline Sorumluluk & 385 & 2,3805 &, 90392 & $-1,525$ & $-0,375$ & 1,00 & 5,00 \\
\hline Yaşam Doyumu & 385 & 3,1605 &, 94676 & $-1,321$ & $-0,241$ & 1,00 & 5,00 \\
\hline
\end{tabular}

Likert tipi ölçek üzerinden elde edilen değişkenlerin normallik sınaması için literatürde kabul gören bir diğer kıstas çarpıklık ve basıklık katsayısı değerlerinin +2 ve -2 arasında olmasıdır (George ve Mallery, 2010). Bu bağlamda Tablo 5 'te verilen değerler faktörlerin istenilen aralıklarda puanlara sahip olduğunu ve verilerin normal dağıldığını göstermektedir. Veriler normal dağılım gösterdiği için verilerin analizinde parametrik testlerden yararlanılmıştır.

\section{Korelasyon Analizi}

Sosyal Medya Kullanım Alışkanlıkları ve Motivasyonları ile Kişilik ve Yaşam Doyumu arasındaki ilişkinin yönünü ve gücünü tespit etmek amacıyla korelasyon analizi yapılmıştır ve elde edilen sonuçlar Tablo 6' da ki gibidir:

Tablo 6. Korelasyon Analizi

\begin{tabular}{|c|c|c|c|c|c|c|c|c|c|c|c|c|}
\hline & 1 & 2 & 3 & 4 & 5 & 6 & 7 & 8 & 9 & 10 & 11 & 12 \\
\hline (1)Uyumluluk & 1 & & & & & & & & & & & \\
\hline (2)Nevrotiklik &, $292 * *$ & 1 & & & & & & & & & & \\
\hline $\begin{array}{l}\text { (3)Deneyime } \\
\text { Açıklık }\end{array}$ & ,678** &, $278 * *$ & 1 & & & & & & & & & \\
\hline (4)Dışa Dönüklük &,- 085 &, $256 * *$ &,- 025 & 1 & & & & & & & & \\
\hline (5)Sorumluluk &,$- 215^{* *}$ &,- 046 &,$- 282 * *$ & ,007 & 1 & & & & & & & \\
\hline (6)Sosyal Kaçış &,- 011 &, $137 * *$ & ,036 & ,007 & ,037 & 1 & & & & & & \\
\hline (7)Sosyal Etkileşim & ,201** &, $205 * *$ &, $208 * *$ &, 022 &,- 036 &, $452 * *$ & 1 & & & & & \\
\hline (8)Bilgilenme & ,206** &, $156 * *$ &, $144 * *$ &,- 053 &,$- 103 *$ &, $365 * *$ &, $503 * *$ & 1 & & & & \\
\hline $\begin{array}{l}\text { (9)Boş Zamanları } \\
\text { Değerlendirme }\end{array}$ &, $251 * *$ &, $191 * *$ &, $220 * *$ &,- 085 &,- 020 &, $415 * *$ & $536 * *$ & ,494** & 1 & & & \\
\hline $\begin{array}{l}\text { (10)Ekonomik } \\
\text { Fayda }\end{array}$ &, $140 * *$ & ,081 &, $143 * *$ &,- 060 &,- 070 &, $349 * *$ &, $548 * *$ & ,491** &, $455^{* *}$ & 1 & & \\
\hline (11)Eğlence & ,065 &, $201 * *$ & ,075 & ,046 &, $119 *$ &, $387 * *$ &, $525 * *$ &, $342 * *$ &, $464 * *$ &, $446^{* * *}$ & 1 & \\
\hline $\begin{array}{l}\text { (12)Yaşam } \\
\text { Doyumu }\end{array}$ & $435 * *$ &, 059 &, $523 * *$ &,- 014 &,$- 202 * *$ &, 065 & , 192** &, $205^{* *}$ &, $207 * *$ &, $175^{* *}$ & ,097 & 1 \\
\hline
\end{tabular}

Doyumu

**. Correlation is significant at the 0.01 level (2-tailed).

*. Correlation is significant at the 0.05level (2-tailed).

Korelasyon analizi sonucunda korelasyon katsayısının büyüklük bakımından yorumlanmasında en yaygın kabul gören aralıklar Büyüköztürk (2010) tarafından şu şekilde belirtilmiştir. Korelasyon katsayısının mutlak değeri 0,70 1,00 arasında ise yüksek ilişkiyi, 0,30-0,70 arasında ise orta düzey ilişkiyi, 0,00 0,30 arasında ise düşük ilişkiyi göstermektedir. Analiz sonuçlarına göre; uyumluluk kişilik özelliği ile sosyal etkileşim, bilgilenme, boş zamanları değerlendirme ve ekonomik fayda motivasyonu arasında pozitif yönde ve düşük düzeyde; nevrotik kişilik özelliği ile sosyal kaçış, sosyal etkileşim, bilgilenme, boş zamanları değerlendirme ve eğlence motivasyonu arasında pozitif yönde ve düşük düzeyde; 
deneyime açıklık kişilik özelliği ile sosyal etkileşim, bilgilenme, boş zamanları değerlendirme ve ekonomik fayda motivasyonu arasında pozitif yönde ve düşük düzeyde; sorumluluk kişilik özelliği ile eğlence motivasyonu arasında pozitif yönde ve düşük düzeyde ilişki tespit edilirken bilgilenme motivasyonu ile negatif yönde ve düşük düzeyde bir ilişki bulunmuştur.

Ayrıca yaşam doyumu ile uyumluluk ve deneyime açıklık kişilik özelliği arasında pozitif yönde ve orta düzeyde, sorumluluk kişilik özelliği ile de negatif yönde ve düşük düzeyde ilişki tespit edilmiştir. Son olarak yaşam doyumu ile sosyal etkileşim, bilgilenme, boş zamanları değerlendirme ve ekonomik fayda motivasyonları arasında pozitif yönde ve düşük düzeyde ilişki olduğu sonucuna ulaşılmıştır.

Değişkenler arasında ilişkinin gücü ve yönü belirlendikten sonra bağımsız değişkenlerin bağımlı değişkeni etkileme durumu için çoklu regresyon analizi gerçekleştirilmiştir.

\section{E. Çoklu Doğrusal Regresyon Analizi Sonuçları}

Beş boyuttan oluşan kişilik özelliklerinin sosyal medya kullanım alışkanlıkları ve motivasyonları ile yaşam doyumu üzerindeki etkisini belirlemek amacıyla çoklu doğrusal regresyon analizi yapılmıştır. Çoklu regresyon analizi varsayımlarından birisi, çoklu bağıntı sorunun olmamasıdır. Çoklu bağıntı sorunun olup olmadığını belirlemek için Tolerans ve VIF değerlerine bakılmalıdır. Bağıntı sorunu olmaması için tolerans değerinin 0,1 'in üzerinde, VIF değerinin 10 'un altında olması gerekmektedir (Hair vd., 2010). Ayrica otokorelasyon sorunu olmaması için de Durbin Watson değerleri 1,5-2,5 arasında olmalıdır (Karagöz, 2019).

Yapılan çoklu regresyon analizi sonucunda değişkenlerin Tolerans değerlerinin 0,1 'in üzerinde, VIF değerlerinin 10'un altında olduğu tespit edilmiş ve çoklu bağıntı problemi olmadığı görülmüştür. Ardından değişkenler arasında otokorelasyonun belirlenmesi için Durbin Watson istatistiği sonuçlarına bakılmış ve otokorelasyon sorunu olmadığı da tespit edilmiştir. Değerler regresyon tablolarında verilmiştir.

Tablo 7. Kişilik Özelliklerinin Sosyal Kaçış Motivasyonuna Etkisine İlişkin Analiz Sonuçları

\begin{tabular}{|c|c|c|c|c|c|c|c|}
\hline \multirow[t]{2}{*}{ Bağımsız Değişkenler } & \multirow[t]{2}{*}{$\beta$} & \multirow[t]{2}{*}{$\mathbf{t}$} & \multirow[t]{2}{*}{$\mathbf{p}$} & \multirow[t]{2}{*}{$\mathbf{F}$} & \multirow[t]{2}{*}{$\begin{array}{c}\text { Model } \\
\text { (p) }\end{array}$} & \multicolumn{2}{|c|}{$\begin{array}{l}\text { Doğrusallık } \\
\text { İstatistikleri }\end{array}$} \\
\hline & & & & & & $\begin{array}{l}\text { Tolerans } \\
\text { Değerleri }\end{array}$ & $\begin{array}{c}\text { VIF } \\
\text { Değerleri }\end{array}$ \\
\hline Sabit & 3,143 & 9,611 & ,000 & \multirow{6}{*}{2,081} & \multirow{6}{*}{,067 } & & \\
\hline Uyumluluk &,- 104 & $-1,404$ & ,161 & & & ,518 & 1,932 \\
\hline Nevrotiklik & ,122 & 2,850 & ,005 & & & ,824 & 1,213 \\
\hline Deneyime Açıklık & ,064 & ,994 & ,321 & & & ,514 & 1,947 \\
\hline Dişa Dönüklük &,- 047 &,- 771 & ,441 & & & ,906 & 1,103 \\
\hline Sorumluluk & 038 & ,812 & ,417 & & & ,918 & 1,089 \\
\hline \multicolumn{8}{|c|}{$\mathrm{R}^{2}:, 027 \quad$ Düzeltilmiş $\mathrm{R}^{2:}, 014 \quad$ Durbin-Watson:1,657 } \\
\hline
\end{tabular}

Kişilik özelliklerinin sosyal medya kullanımı ve motivasyonları alt boyutlarından sosyal kaçış motivasyonu üzerindeki etkisine bakıldığında, nevrotik kişilik özelliği sosyal kaçış motivasyonu üzerinde istatistiki açıdan anlamlı bir etkiye sahip iken diğer kişilik özellikleri anlamlı bir etkiye sahip değildir. Amiel ve 
Sargent (2004), nevrotik kişilik özelliği yüksek olan bireylerin, e-posta ve telefon numarası gibi kişisel bilgilerini vermeyi tercih etmediklerini ve Facebook'un iletişim özellikleriyle çok ilgilenmediklerini belirtmişlerdir.

Tablo 8. Kişilik Özelliklerinin Sosyal Etkileşim Motivasyonuna Etkisine İlişkin Analiz Sonuçları

\begin{tabular}{|c|c|c|c|c|c|c|c|}
\hline \multirow[t]{2}{*}{ Bağımsız Değișkenler } & \multirow[t]{2}{*}{$\beta$} & \multirow[t]{2}{*}{$\mathbf{t}$} & \multirow[t]{2}{*}{$\mathbf{p}$} & \multirow[t]{2}{*}{$\mathbf{F}$} & \multirow[t]{2}{*}{$\begin{array}{c}\text { Model } \\
\text { (p) }\end{array}$} & \multicolumn{2}{|c|}{$\begin{array}{l}\text { Doğrusallık } \\
\text { İstatistikleri }\end{array}$} \\
\hline & & & & & & $\begin{array}{l}\text { Tolerans } \\
\text { Değerleri }\end{array}$ & $\begin{array}{c}\text { VIF } \\
\text { Değerleri }\end{array}$ \\
\hline Sabit & 2,396 & 6,574 &, 000 & \multirow{6}{*}{5,762} & \multirow{6}{*}{,000 } & & \\
\hline Uyumluluk & ,098 & 1,189 & ,235 & & & ,518 & 1,932 \\
\hline Nevrotiklik &, 132 & 2,771 & ,006 & & & ,824 & 1,213 \\
\hline Deneyime Açıklık &, 121 & 1,685 & ,093 & & &, 514 & 1,947 \\
\hline Dışa Dönüklük &,- 009 &,- 137 & ,891 & & & ,906 & 1,103 \\
\hline Sorumluluk &, 021 & ,413 & 680 & & & ,918 & 1,089 \\
\hline Düzeltilmi & $\mathrm{R}^{2:}:, 058$ & Durl & Natsor & & & & \\
\hline
\end{tabular}

Sosyal medya kullanıcıların nevrotik kişilik özelliği sosyal etkileşim motivasyonu üzerinde anlamlı bir etkiye sahiptir $(\mathrm{p}=0,000<0.05)$. Dolayısiyla " $\mathrm{H}_{2}$ :Sosyal medya kullanıcılarının kişilik özelliklerinin sosyal etkileşim motivasyonu üzerinde anlamlı bir etkisi vardır" hipotezi nevrotik kişilik özelliği bakımından desteklenmiştir. Elde edilen bulgu ile benzer bir bulgu da AmichaiHamburger ve Vinitzly, (2010) tarafından yapılan çalışmada tespit edilmiş ve nevrotiklerin Facebook'u daha çok sosyalleşme aracı olarak kullandıkları ve daha çok kişisel bilgi paylaştıkları görülmüştür. Ayrıca sosyal medya kullanıcılarının kişilik özelliklerinin sosyal etkileşim ve sosyal medya motivasyonlarını açıklama orant ise $\% 5,8$ 'dir.

Tablo 9. Kişilik Özelliklerinin Bilgilenme Motivasyonuna Etkisine İlişkin Analiz Tablosu

\begin{tabular}{|c|c|c|c|c|c|c|c|}
\hline \multirow[t]{2}{*}{ Bağımsız Değişkenler } & \multirow[t]{2}{*}{$\beta$} & \multirow[t]{2}{*}{$\mathbf{t}$} & \multirow[t]{2}{*}{$\mathbf{p}$} & \multirow[t]{2}{*}{$\mathbf{F}$} & \multirow{2}{*}{$\begin{array}{c}\text { Model } \\
\text { (p) }\end{array}$} & \multicolumn{2}{|c|}{ Doğrusallık İstatistikleri } \\
\hline & & & & & & $\begin{array}{l}\text { Tolerans } \\
\text { Değerleri }\end{array}$ & $\begin{array}{c}\text { VIF } \\
\text { Değerleri }\end{array}$ \\
\hline Sabit & 3,057 & 9,010 &, 000 & \multirow{6}{*}{4,975} & \multirow{6}{*}{,000 } & & \\
\hline Uyumluluk &, 181 & 2,364 & ,019 & & & ,518 & 1,932 \\
\hline Nevrotiklik & 106 & 2,382 &, 018 & & & 824 & 1,213 \\
\hline Deneyime Açıklık &,- 023 &,- 341 & 734 & & & ,514 & 1,947 \\
\hline Dışa Dönüklük &,- 087 & $-1,390$ &, 165 & & & 906 & 1,103 \\
\hline Sorumluluk &,- 063 & $-1,308$ & 192 & & & ,918 & 1,089 \\
\hline Düzeltilmi & 049 & urbin-W & on: 1,9 & & & & \\
\hline
\end{tabular}

Tablo 9'a göre; sosyal medya kullanıcılarının uyumluluk ve nevrotik kişilik özelliğinin bilgilenme motivasyonu üzerinde anlamlı bir etkiye sahip olduğu tespit edilmiştir. Mevcut çalışma ile paralel bir sonuçta Lin vd. (2017) tarafından yapılan çalışmada elde edilmiştir. Lin vd.(2017), nevrotikliğin Facebook ve Pinterest platformlarının kullanımı için bilgi arama motivasyonu üzerinde olumlu bir etkisinin olduğu sonucuna ulaşmışlardır.

Tablo 10.Kişilik Özelliklerinin Boş Zamanları Değerlendirme Motivasyonuna Etkisine İlişkin Analiz Tablosu

\begin{tabular}{|l|c|c|c|c|c|c|c|}
\hline Bağımsız Değişkenler & $\boldsymbol{\beta}$ & $\mathbf{t}$ & $\mathbf{p}$ & $\mathbf{F}$ & $\begin{array}{c}\text { Model } \\
(\mathbf{p})\end{array}$ & \multicolumn{2}{|c|}{$\begin{array}{c}\text { Doğrusallık } \\
\text { İstatistikleri }\end{array}$} \\
\cline { 1 - 4 } & & & & & & $\begin{array}{c}\text { Tolerans } \\
\text { Değerleri }\end{array}$ & $\begin{array}{c}\text { VIF } \\
\text { Değerleri }\end{array}$ \\
\hline Sabit & & & & & & & \\
\hline Uyumluluk & 2,687 & 7,673 &, 000 & & &, 518 & 1,932 \\
\hline Nevrotiklik &, 171 & 2,162 & $\mathbf{, 0 3 1}$ & & &, 824 & 1,213 \\
\hline
\end{tabular}




\begin{tabular}{|l|c|c|c|c|c|c|r|}
\hline Deneyime Açıklık &, 089 & 1,280 &, 201 & \multirow{2}{*}{7,859} & \multirow{2}{*}{, 000} &, 514 & 1,947 \\
\hline Dişa Dönüklük &,- 139 & $-2,138$ & $\mathbf{, 0 3 3}$ & & &, 906 & 1,103 \\
\hline Sorumluluk &, 043 &, 869 &, 386 & & &, 918 & 1,089 \\
\hline $\mathrm{R}^{2}:, 094$ & & & \\
\hline
\end{tabular}

Kişilik özelliklerinin boş zamanları değerlendirme motivasyonunu açıklama oranı \% 8,2'dir. Yapılan analiz sonucuna göre; uyumluluk, nevrotiklik ve dışa dönüklük kişilik özelliğinin boş zamanları değerlendirme motivasyonu üzerinde anlamlı bir etkisi olduğu görülmektedir. Lu ve $\mathrm{Hu}$ (2005) yaptıkları çalışmada, dışa dönüklük kişilik özelliği ile boş zamanları değerlendirme arasında anlamlı bir ilişki bulmuşlardır ve bu sonuç elde edilen bulguyu destekler niteliktedir.

Tablo 11.Kişilik Özelliklerinin Ekonomik Fayda Motivasyonuna Etkisine İlişkin Analiz Tablosu

\begin{tabular}{|c|c|c|c|c|c|c|c|}
\hline \multirow[t]{2}{*}{ Bağımsız Değişkenler } & \multirow[t]{2}{*}{$\beta$} & \multirow[t]{2}{*}{$\mathbf{t}$} & \multirow[t]{2}{*}{$\mathbf{p}$} & \multirow[t]{2}{*}{$\mathbf{F}$} & \multirow[t]{2}{*}{$\begin{array}{c}\text { Model } \\
\text { (p) }\end{array}$} & \multicolumn{2}{|c|}{$\begin{array}{l}\text { Doğrusallık } \\
\text { İstatistikleri }\end{array}$} \\
\hline & & & & & & $\begin{array}{l}\text { Tolerans } \\
\text { Değerleri }\end{array}$ & $\begin{array}{c}\text { VIF } \\
\text { Değerleri }\end{array}$ \\
\hline Sabit & 3,115 & 7,510 & ,000 & \multirow{6}{*}{2,364} & \multirow{6}{*}{,039 } & & \\
\hline Uyumluluk &, 076 & 814 & 416 & & & ,518 & 1,932 \\
\hline Nevrotiklik & 057 & 1,054 & ,293 & & & 824 & 1,213 \\
\hline Deneyime Açıklık & 090 & 1,097 &, 273 & & & ,514 & 1,947 \\
\hline Dışa Dönüklük &,- 099 & $-1,286$ & 199 & & & 906 & 1,103 \\
\hline Sorumluluk &,- 036 &,- 617 & ,538 & & & ,918 & 1,089 \\
\hline Düzeltilmis & 017 & Jurbin-W & n: $1,8^{\prime}$ & & & & \\
\hline
\end{tabular}

Tablo 11'e göre sosyal medya kullanıcılarının kişilik özelliklerinin hiçbirinin ekonomik fayda motivasyonu üzerinde anlaml edilememiştir. Dolayısıyla " $\mathrm{H}_{5}:$ Sosyal medya kullanıcılarının kişilik özelliklerinin ekonomik fayda motivasyonu üzerinde anlamlı bir etkisi vardır" hipotezi red edilmiștir.

Tablo 12.Kișilik Özelliklerinin Eğlence Motivasyonuna Etkisine İlişkin Analiz Tablosu

\begin{tabular}{|c|c|c|c|c|c|c|c|}
\hline \multirow[t]{2}{*}{$\begin{array}{l}\text { Bağımsız } \\
\text { Değişkenler }\end{array}$} & \multirow[t]{2}{*}{$\beta$} & \multirow[t]{2}{*}{$\mathrm{t}$} & \multirow[t]{2}{*}{$\mathbf{p}$} & \multirow[t]{2}{*}{$\mathbf{F}$} & \multirow[t]{2}{*}{$\begin{array}{c}\text { Model } \\
\text { (p) }\end{array}$} & \multicolumn{2}{|c|}{$\begin{array}{l}\text { Doğrusallık } \\
\text { İstatistikleri }\end{array}$} \\
\hline & & & & & & $\begin{array}{l}\text { Tolerans } \\
\text { Değerleri }\end{array}$ & $\begin{array}{c}\text { VIF } \\
\text { Değerleri }\end{array}$ \\
\hline Sabit & 2,202 & 5,026 & 000 & \multirow{6}{*}{4,855} & \multirow{6}{*}{,000 } & & \\
\hline Uyumluluk &,- 006 & $\begin{array}{l}-062 \\
-062\end{array}$ & ,951 & & & ,518 & 1,932 \\
\hline Nevrotiklik & ,200 & 3,490 & ,001 & & & 824 & 1,213 \\
\hline Deneyime Açıklık &, 082 & ,943 & ,346 & & & ,514 & 1,947 \\
\hline Dışa Dönüklük & $\begin{array}{l}-, 004 \\
\end{array}$ & $\begin{array}{l}-, 053 \\
\end{array}$ & ,958 & & & ,906 & 1,103 \\
\hline Sorumluluk &, 174 & 2,794 & ,005 & & & 918 & 1,089 \\
\hline $\mathrm{R}^{2: 060}$ & :048 & urbin-Wa & on: 1,65 & & & & \\
\hline
\end{tabular}

Yapılan analiz sonucuna göre; nevrotiklik ve sorumluluk kişilik özelliği eğlence motivasyonu üzerinde istatistiki açıdan anlamlı bir etkiye sahiptir. Kalmus vd.(2011) tarafından yapılan çalışmanın sonuçlarına göre; nevrotik düşüncelere sahip olan bireyler, sosyal medyayı eğlence amaçlı kullanmaya daha çok eğilimlidirler.

Tablo 13.Kişilik Özelliklerinin Yaşam Doyumuna Etkisine İlişkin Analiz Sonuçlanı

\begin{tabular}{|c|c|c|c|c|c|c|c|}
\hline \multirow[t]{2}{*}{ Bağımsız Değişkenler } & \multirow[t]{2}{*}{$\beta$} & \multirow[t]{2}{*}{$\mathbf{t}$} & \multirow[t]{2}{*}{ p } & \multirow[t]{2}{*}{$\mathbf{F}$} & \multirow{2}{*}{$\begin{array}{l}\text { Model } \\
\text { (p) }\end{array}$} & \multicolumn{2}{|c|}{ Doğrusallık İstatistikleri } \\
\hline & & & & & & $\begin{array}{l}\text { Tolerans } \\
\text { Değerleri }\end{array}$ & $\begin{array}{c}\text { VIF } \\
\text { Değerleri }\end{array}$ \\
\hline Sabit & ,901 & 2,730 & ,007 & & & & \\
\hline Uyumluluk & 220 & 2,950 &, 003 & & & .518 & 1.932 \\
\hline
\end{tabular}




\begin{tabular}{|c|c|c|c|c|c|c|c|}
\hline Nevrotiklik &,- 113 & $-2,608$ & ,009 & \multirow{4}{*}{32,566} & \multirow{4}{*}{,000 } & ,824 & 1,213 \\
\hline Deneyime Açıklık & ,462 & 7,078 & ,000 & & & ,514 & 1,947 \\
\hline Dışa Dönüklük &, 059 & ,964 & ,335 & & & ,906 & 1,103 \\
\hline Sorumluluk &,- 053 & $-1,126$ & 261 & & & 918 & 1,089 \\
\hline $\mathrm{R}^{2}:, 301$ & :291 & Durbin- & on: 2,1 & & & & \\
\hline
\end{tabular}

Sosyal medya kullanıcılarının kişilik özelliklerinin yaşam doyumuna etkisini tespit etmek amaciyla yapılan analiz sonucuna göre; uyumluluk, nevrotiklik ve deneyime açıklık kişilik özelliği yaşam doyumu üzerinde anlamlı bir etkiye sahiptir. Sosyal medya kullanıcılarının kişilik özelliklerinin yaşam doyumunu açıklama oranı \%29,1'dir. " $\mathrm{H}_{7}$ :Sosyal medya kullanıcılarının kişilik özelliklerinin yaşam doyumu üzerinde anlamlı bir etkisi vardır" hipotezi uyumluluk, nevrotiklik ve deneyime açıklık özellikleri bakımından kabul edilmiştir.

Araştırmada son olarak sosyal medya kullanım alışkanlıkları ve motivasyonlarının yaşam doyumu üzerindeki etkisini incelemek için çoklu regresyon analizi yapılmış ve analiz sonucu aşağıdaki gibidir:

Tablo 14. Sosyal Medya Motivasyonlarının Yaşam Doyumuna Etkisine İlişkin Analiz Sonuçları

\begin{tabular}{|c|c|c|c|c|c|c|c|}
\hline \multirow[t]{2}{*}{ Bağımsız Değişkenler } & \multirow[t]{2}{*}{$\beta$} & \multirow[t]{2}{*}{$\mathbf{t}$} & \multirow[t]{2}{*}{$\mathbf{p}$} & \multirow[t]{2}{*}{$\mathbf{F}$} & \multirow[t]{2}{*}{$\begin{array}{l}\text { Model } \\
\text { (p) }\end{array}$} & \multicolumn{2}{|c|}{$\begin{array}{l}\text { Doğrusallık } \\
\text { İstatistikleri }\end{array}$} \\
\hline & & & & & & $\begin{array}{l}\text { Tolerans } \\
\text { Değerleri }\end{array}$ & $\begin{array}{c}\text { VIF } \\
\text { Değerleri }\end{array}$ \\
\hline Sabit & 2,075 & 7,902 & 000 & \multirow{7}{*}{4,574} & \multirow{7}{*}{, 000} & & \\
\hline Sosyal Kaçış Motivasyonu &,- 086 & $-1,234$ & 218 & & & ,727 & 1,376 \\
\hline $\begin{array}{ll}\text { Sosyal } & \text { Etkileşim } \\
\text { Motivasyonu } & \end{array}$ & ,097 & 1,335 &, 183 & & & 507 & 1,974 \\
\hline Bilgilenme Motivasyonu &, 123 & 1,737 &, 083 & & & 629 & 1,590 \\
\hline $\begin{array}{l}\text { Boş Zamanları Değerlendirme } \\
\text { Motivasyonu }\end{array}$ & 138 & 1,984 & ,048 & & & ,590 & 1,695 \\
\hline $\begin{array}{l}\text { Ekonomik } \\
\text { Motivasyonu }\end{array}$ & 055 & ,911 & ,363 & & & ,604 & 1,657 \\
\hline Eğlence Motivasyonu &,- 041 &,- 754 & 451 & & & 644 & 1,552 \\
\hline
\end{tabular}

Yapılan analiz sonucuna göre sadece boş zamanları değerlendirme motivasyonun yaşam doyumu üzerinde anlamlı bir etkisi bulunurken diğer sosyal medya motivasyonlarının yaşam doyumu üzerinde anlamlı bir etkisi tespit edilememiştir. Dolayısıyla "sosyal medya kullanım motivasyonlarının yaşam doyumu üzerinde anlamlı bir etkisi vardır" hipotezi sadece boş zamanları değerlendirme motivasyonu bakımından desteklenmiştir.

\section{SONUÇ}

Sosyal ağların kullanıcı sayısındaki çarpıcı artış, sosyal medyanın özellikle genç nüfus arasında yaygın kullanımı ve yaşamın ayrılmaz bir parçası haline gelmesi gibi nedenler sosyal medya kullanma motivasyonlarının belirlemesine yönelik çalışmalara olan ilgiyi artırmıştır. Bu kapsamda bu çalışmada sosyal medya kullanım motivasyonlarının kişilik ve yaşam doyumu açısından incelenmesi amaçlanmıştır.

Araştırma bulgularına göre; uyumluluk kişilik özelliği ile sosyal etkileşim, bilgilenme, boş zamanları değerlendirme, ekonomik fayda motivasyonları arasında pozitif yönde ve düşük düzeyde ilişki vardır. Uyumluluk özelliği yüksek olan bireyler başkaları tarafindan paylaşılan içeriğe beğeniler ve yorumlarla daha fazla katılmakta (Choi vd., 2017) ve profillerine daha çok arkadaş eklemektedirler (Ross 
vd., 2009). Bu durum uyumlu bireylerin sosyal etkileşim düzeyleriyle ilişkisini ifade etmektedir. Elde edilen bulgularla paralellik gösteren bir çalışma Zuniga vd. (2017) tarafından yapılmış ve çalışmada yüksek uyumluluğa sahip bireylerin sosyal medyayı daha sık kullandıklarını ve başkalarıyla etkileşimde bulunduklarını tespit etmişlerdir.

Nevrotik kişilik özelliği ile sosyal kaçış, sosyal etkileşim, bilgilenme, boş zamanları değerlendirme ve eğlence motivasyonları arasında pozitif yönde ve düşük düzeyde ilişki tespit edilen bir diğer araştırma bulgusudur. Nevrotik bireyler, genellikle sosyal medyayı kendileri gibi olanları veya benzer düşüncelere sahip olanları bulma, sosyal destek veya sorunlarıyla nasıl başa çıkacaklarını öğrenme firsatları için kullanabilmektedirler. Literatüre bakıldığında özellikle nevrotik kişilik özelliği ile sosyal etkileşim arasındaki ilişkilere yönelik çalışmalar mevcuttur. Bu çalışmalardan biri Wolfradt ve Doll (2001) tarafindan yapılmış ve çalışmada nevrotizmi yüksek bireylerin yüksek düzeyde sosyal çıkarlarla birleştirildiğinde interneti iletişim için kullanmaya büyük ilgi gösterdikleri tespit edilmiştir. Aynı zamanda Swickert vd. (2002), nevrotik düşüncesi fazla olan bireyler için arkadaşlık kurmak ve dost edinmenin sosyal medya kullanımında motive edici faktörler olduğunu ifade etmişlerdir. Kalmus vd. (2011) tarafından yapılan çalışmada mevcut çalışmayla kısmen paralellik göstermektedir. Kalmus vd. (2011) deneyimlere açık olan ve nevrotik düşüncelere sahip olan bireylerin sosyal medyayı eğlence amaçlı kullanmaya daha çok eğilimli oldukları sonucuna ulaşmışlardır.

Sosyal medya kullanıcılarının deneyime açıklık kişilik özelliği ile sosyal etkileşim, bilgilenme, boş zamanları değerlendirme ve ekonomik fayda arasında pozitif yönde ve düşük düzeyde ilişki olduğu mevcut çalışmada tespit edilmiştir. Deneyimlere açık olan bireyler, sosyal medyayı sıklıkla kullanmakta ve daha çok bilgi paylaşımında bulunmak ve tavsiye vermek amacıyla iletişim kurmaktadırlar (Kalmus vd., 2011). Mevcut çalışmada sorumluluk kişilik özelliği ile eğlence motivasyonu arasında pozitif yönde ve düşük düzeyde ilişki bulunurken bilgilenme motivasyonu arasında negatif yönde ve düşük düzeyde ilişki bulunmuştur. Sorumluluk düzeyi daha yüksek olan bireylerin daha bilinçli oldukları varsayıldığından bu bireyler sosyal medyada geçirilen zamanın boşa harcandığını düşünerek, bilgi edinebilmek amacıyla daha farklı bilgi kaynaklarını tercih edebilirler şeklinde bu bulgu yorumlanabilir.

Sosyal medya kullanıcılarının yaşam doyumları ile sosyal etkileşim, bilgilenme, boş zamanları değerlendirme, ekonomik fayda motivasyonları arasında pozitif yönde ve düşük düzeyde ilişki olduğu tespit edilmiştir. Bu sonuçlarla paralellik gösteren çalışmalar mevcuttur. Baldwin ve Tinsley (1998) ve Wankel ve Berger (1990) boş zaman aktivitelerine katılmanın yaşam memnuniyeti ile pozitif bir korelasyona sahip olduğunu belirtmişlerdir. Lloyd ve Auld (2002) çalışmalarında, boş zamanla ilgili artan memnuniyet ve boş zaman faaliyetlerine katılım sıklığının yaşam memnuniyeti ile pozitif korelasyon gösterdiğini ifade etmişlerdir. TandocJr vd. (2015) tarafından yapılan çalışmada ise, iletişim ve 
sosyalleşme sağladığı için Facebook kullanımının depresyonu azalttığı sonucuna ulaşılmıştır.

Araştırmadan elde edilen bir diğer bulgu ise, sosyal medya kullanıcılarının kişilik özelliklerinden nevrotik kişilik özelliğinin sosyal medya kullanım alışkanları ve motivasyonlarından sosyal kaçış, sosyal etkileşim, bilgilenme, boş zamanları değerlendirme ve eğlence motivasyonları üzerinde anlamlı bir etkisinin olduğudur. Bu sonuç Amiel ve Sargent (2004), Amichai-Hamburger ve Vinitzly (2010), Lin vd. (2017) ve Kalmus vd. (2011) tarafından yapılan çalışmaların bulguları ile benzerlik göstermektedir.

Ayrıca sosyal medya kullanıcılarının uyumluluk, nevrotiklik ve deneyime açıklık kişilik özelliğinin yaşam doyumu üzerinde anlamlı bir etkiye sahip olduğu sonucuna ulaşılmıştır. Son olarak da çalışmada, boş zamanları değerlendirme motivasyonun yaşam doyumu üzerinde anlamlı bir etkisi tespit edilmiştir. Baldwin ve Tinsley (1998), Wankel ve Berger (1990) ve Lloyd ve Auld (2002) tarafindan yapılan çalışmalar da bu bulguyu desteklemektedir.

$\mathrm{Bu}$ araştırmanın en önemli kısıtları araştırmada kullanılan soru sayısının fazlalığıdır. $\mathrm{Bu}$ durum araştırmaya katılanların sorulara verdikleri cevapların doğruluğunu etkileyebilecek bir unsurdur. Araştırmanın diğer kısıtları ise verilerin kısa bir zaman dilimi içerisinde online olarak toplanması ve sosyal medya kullanım alışkanlıkları ve motivasyonlarından sadece altı tanesinin kullanılmasıdır. $\mathrm{Bu}$ nedenlerle sonraki araştırmalarda daha fazla sosyal medya motivasyonunu ölçen ama daha sade ölçekler kullanılarak daha büyük örneklem sayısı ve farklı analiz teknikleri ile çalışmaların yapılması önerilmektedir.

\section{Araştırma ve Yayın Etiği Beyanı}

Makalenin tüm süreçlerinde Yönetim ve Ekonomi Dergisi'nin araştırma ve yayın etiği ilkelerine uygun olarak hareket edilmiştir.

\section{Yazarların Makaleye Katkı Oranları}

Makalenin tamamı Doç. Dr. Şükran KARACA tarafindan kaleme alınmıştır.

\section{Çıkar Beyanı}

Yazarın herhangi bir kişi ya da kuruluş ile çıkar çatışması yoktur.

\section{KAYNAKÇA}

Alexa (2020). The top 500 sites on the web. Retrieved April 24, 2020, from: https://www.alexa.com/topsites.

Alhabash, S. and Ma, M. (2017). A Tale of Four Platforms: Motivations and Uses of Facebook, Twitter, Instagram, and Snapchat Among College Students? Social Media+ Society.

Amichai-Hamburger, Y. and Vinitzky, G. (2010). Social Network Use And Personality. Comput. Hum. Behav, Vol. 26, 1289-1295. doi: 10.1016/j.chb.2010.03.018

Amiel, T. and Sargent, S. L. (2004). Individual Differences İn Internet Usage Motives. Computers in Human Behavior, Vol.20, No.6, 711-726.

Avcılar, M. Y. ve Külter Demirgüneş, B. (2016). Kişilik Özelliklerinin Sosyal Medya Kullanım Motivasyonları Üzerindeki Etkilerinin Tespiti. Journal of Management, Marketing and Logistics, Cilt 3, Say1 3, 251-271.

Baldwin. K. and Tinsley, H. (1988). An investigation of the validity of Tinsley and Tinsley's (1986). Theory of leisure experience. Journal of Counseling Psychology, Vol. 35, No..3, 263-267.

Bollen, J., Gonçalves, B., Ruan, G. and Mao, H. (2011). Happiness is Assortative İn Online Social Networks. Artificial Life, Vol.17, No.3, 237-251. doi:10.1162/artl_a_00034 
Butt, S. and Phillips, J. G. (2008). Personality and Self-Reported Mobile Phoneuse. Comput. Hum. Behav., Vol 24, 346-360. doi: 10.1016/j.chb.2007.01.019

Carr, C. T. and Hayes, R. A. (2015). Social Media: Defining, Developing, And Divining. Atlantic Journal Of Communication, Vol. 23, 46-65.

Cha J. (2010). Factors Affecting The Frequency And Amount Of Social Networking Site Use: Motivations, Perceptions, And Privacy Concerns, First Monday, Vol.15, No.12, 2-16.

Choi, T. R., Sung, Y., Lee, J. A. and Choi, S. M. (2017). Get Behind My Selfies: The Big Five Traits And Social Networking Behaviors Through Selfies. Personality and Individual Differences, Vol. 109, 98-101.

Clore, G. L.,Wyer Jr, R. S., Dienes, B., Gasper, K., Gohm, C. and Isbell, L. (2001). Affective Feelings As Feedback: Some Cognitive Consequences. In L. L. Martin, ve G. L. Clore (Eds.), Theories of mood and cognition: A User's Guide Book (pp. 27-62). Mahwah, NJ, US: Lawrence Erlbaum Associates Publishers.

Diener, E., Sandvik, E. and Pavot, W. (2009). Happiness is The Frequency, Not The Intensity, Of Positive Versus Negative Affect. In E. Diener (Ed.), Assessing Well-Being (Vol. 39, pp. 213-231). Netherlands: Springer.

Diener, E.,Emmons, R. A., Larsen, R. J. and Griffin, S. (1985). The Satisfaction With Life Scale. Journal of Personality Assessment, Vol. 49, No.1, 71-75. doi:10.1207/s15327752jpa4901_13

Doğan, U. (2016). Effects of Social Network Use on Happiness, Psychological Well-being, and Life Satisfaction of High School Students: Case of Facebook and Twitter. Educationand Science, Vol 41, 217-229.

Fullwood, C., Nicholls, W. and Makichi, R. (2014). We've Got Something For Everyone: How İndividual Differences Predict Different Blogging Motivations. New Media Soc., Vol. 17, 1583-1600. doi: 10.1177/1461444814530248

George, D., and Mallery, M. (2010). SPSS for Windows Step by Step: A Simple Guide and Reference. Boston: Pearson.

Ghaisani, A. P., Handayani, P. W., and Munajat, Q. (2017). Users' Motivation in Sharing Information on Social Media. Procedia Computer Science, Vol.124, 530-535. https://doi.org/10.1016/j.procs.2017.12.186

Google+ (2020). About Google+. Retrieved April 1, 2020, from: https://plus.google.com/about?hl=tr.

Gosling, S. D., Augustine, A. A., Vazire, S., Holtzman, N. and Gaddis, S. (2011). Manifestations of Personality İn Online Socia Lnetworks: Self-Reported Facebook-Related Behaviors And Observable Profile Information. Cyberpsychol. Behav. Soc. Netw, Vol 14, 483-488. doi: 10.1089/cyber.2010.0087

Hair, J., Black, W. C., Babin, B. J., and Anderson, R. E. (2010). Multivariate data analysis (7th ed.). Upper saddle River, New Jersey: Pearson Education International.

Horzum, M. B. (2016). Examining The Relationship To Gender And Personality On The Purpose Of Facebook Usage Of Turkish University Students. Computers in Human Behavior, Vol. 64, 319-328.

INTECO (2009): "Estudiosobre la privacidad de losdatospersonales y la Seguridad De La İnformación En Lasredes Sociales Online". Instituto Nacional de Tecnología de la Comunicación y AgenciaEspañola de Protección de datos, Observatorio de la seguridad de la información, http://creativecommons.org

Jamal J. Al-Menayes (2015). Motivationsfor Using Social Media: An ExploratoryFactor Analysis, International Journal of Psychological Studies, Vol. 7, No. 1, 43-50.

Junco, R. (2013). Comparing Actual and Self-Reported Measures Of Facebook Use. Computers in Human Behavior, Vol. 29, No. 3, 626-631

Kahneman, D. and Krueger, A. B. (2006). Developments In The Measurement Of Subjective WellBeing. The Journal of Economic Perspectives, Vol.20, No. 1, 3-24.

Karagöz, Y. (2019).SPSS- AMOS-META Uygulamalı İstatistiksel Analizler, Ankara: Nobel Yayıncilik. 
Karapanos, E.,Teixeira, P. and Gouveia, R. (2016). Need Fulfillment And Experiences On Social Media: A Case On Facebook And Whatsapp. Computers in Human Behavior, Vol. 55, 888897.

Katz, E., Blumler, J. G. and Gurevitch, M. (1973). Uses and Gratifications Research. Public Opinion Quarterly, Vol. 37, No. 4, 509-523.

Khan, M. L. (2017). Social Media Engagement: What Motivates User Participation And Consumption On Youtube? Computers in Human Behavior, Vol.66, 236-247.

Kim, J. W. and Chock, T. M. (2017). Personality Traits And Psychological Motivations Predicting Selfie Posting Behaviors On Social Networking Sites. Telematics and Informatics, Vol. 34, No.5, 560-571.

Kuss, D. J. and Griffiths, M. D. (2017). Social Networking Sites And Addiction: Ten Lessons Learned. International Journal of Environmental Research and Public Health, Vol. 14, 311.

Landers, R. N. and Lounsbury, J. W. (2006). An Investigation Of Big Five And Narrow Personality Traits In Relation To Internet Usage. Computers in Human Behavior, Vol.22, 283-293.

Layard, R. (2005). Happiness: Lessonsfrom a Newscience. London: Penguin Books.

Leary, M. R. and Kowalski, R. M. (1990). Impression Management: A Literatüre Review And Two Component Model. Psychological Bulletin, Vol. 107, No.1, 34-47. doi:10.1037/00332909.107.1.34

Lee, E.,Ahn, J. and Kim, Y. J. (2014). Personality Traits And Self-Presentation at Facebook. Pers. Individ. Diff. Vol. 69, 162-167. doi: 10.1016/j.paid.2014.05.020

Li, Yuhui, Huang, Zhaoxhing, Wu, YenchunJim and Wang, Zhiqiang (2019). Exploring How Personality Affects Privacy Control Behavior on Social Networking Sites, Front. Psychol, Vol. 10,1771

Lin, Jhih-Syuani Lee, Yen-I, Jin, Yan and Gilbreath, Bob (2017). Cyberpsychology, Behavior, and Social Networking, Vol. 20, No.10, 615-623.

Liu, I. L. B., Cheung, C. M. K. and Lee, M. K. O. (2010). Understanding Twitter Usage: What Drive People Continue T Otweet. in PACIS 2010 Proceedings (p. 92). Pacific Asia Conference on Information Systems: Kaohsiung, Taiwan.

Livingstone, S. (2010). Taking Risky Opportunities İn Youth Fulcontent Creation: Teenagers' Use Of Social Networking Sites Forintimacy, Privacyand Self-Expression. New Media \&. Society, Vol. 10, No..3, 393-411.

Lloyd, K. and Auld, C. J. (2002). The Role of Leisure in Determining Quality Of Life: Issues of Content and Measurement. Social Indicators Research, Vol.57, No.1, 43-71.

$\mathrm{Lu}$, Luo and Hu, Chia-Hsin (2005). Personality, Leisure Experiences and Happiness. Journal of Happiness Studies, Vol. 6, No.3, 325-342.

Misoch, S. (2015). Stranger on The Internet: Online Self-Disclosure and The Role Of Visual Anonymity. Computers in Human Behavior, Vol.48, 535-541.

Moore, K. and McElroy, J. C. (2012). The Influence Of Personality On Facebook Usage, Wall Postings, And Regret. Computers in Human Behavior, Vol. 28, No.1, 267-274.

Obi, A. N. (2014). Time Spend on Facebook vs. Total Time Spent Online: Effects On The Quality Of Life On High School Students (Unpublished Doctoral Thesis). Golden GateUniversity, USA.

Ong, E. Y. ,Ang, R. P., Ho, J., Lim, J. C., Goh, D. H., Lee, C. S., and Chua, A. (2011). Narcissism, Extraversion And Adolescents' Self-Presentation On Facebook, Pers. Individ. Dif. Vol.50, 180-185. doi: 10.1016/j.paid.2010.09.022

Papacharissi, Z. and Rubin, A. M. (2000). Predictors of İnternet Use. Journal of Broadcasting \& Electronic Media, Vol. 44, No. 2, 175-196.

Quan-Haase, A. and Young, A.L. (2010) Uses and Gratifications of Social Media: A Comparison of Facebook and Instant Messaging. Bulletin of Science, Technology \& Society, Vol.30, 350361.

Rae, J. R. and Lonborg, S. D. (2015). Do Motivations Forusing Facebook Moderate The Association Between Facebook Use And Psychological Well-Being? Frontiers in Psychology, Vol. 6, 771. 
Ross, C., E.S. Orr, M. Sisic, J.M. Arseneault, M.G. Simmering and R.R. Orr (2009). Personality and Motivations Associated with Facebook Use. Computers in Human Behavior, Vol. 25, 578586.

Rubin, A. M. (1993). Audience Activity And Media Use. Communications Monographs, Vol. 60, No.1, 98-105.

Ruggiero T. E. (2000). Uses and Gratifications Theory in the 21st century. Mass Communication and Society, Vol. 3, No.1, 3-37.

Ryan, T., and Xenos, S. (2011). Who Uses Facebook? An İnvestigation İnto The Relationship Between The Big Five, Shyness, Narcissism, Loneliness, And Facebook Usage. Computers in Human Behavior, Vol. 27, No.5, 1658-1664.

Scheufele, D. A. and Shah, D. V. (2000). Personality Strength And Social Capital: The Role Of Dispositional And İnformational Variables İn The Production Of Civic Participation. Journal of Communication Research, Vol.2, No.2, 107-131.

Seidman, G. (2012). Self-Presentation And Belonging On Facebook: How Personality İnfluences Social Media Use And Motivations. Pers. Individ. Dif, Vol. 54, 402-407. doi: 10.1016/j.paid.2012.10.009

Swickert, R., Hittner, J., Harris, J. and Herring, J. (2002). Relationships Among Internet Use, Personality, And Social Support. Computers in Human Behavior, Vol.18, No.4, 437-451.

TandocJr, E. C., Ferrucci, P. and Duffy, M. (2015). Facebook Use, Envy, And Depression Among College Students: Is Facebooking Depressing? Computers in Human Behavior, Vol.43, 139-146.

Tsai, Lien-Hsiang (2003). Relationships Between Personality Attributes and Internet Marketing, A Dissertation, Alliant International Unıversity, UMI.

Tuncer, D., Arpac1, T., Ayhan, Y., Böge, E. ve Üner, M. (1992). Pazarlama. Ankara: Gazi Yayınları.

Urista, M.A.,Dong, Q. and Day, K.D. (2009). Explaining Why Young Adults Use My Space And Facebook Through Uses And Gratifications Theory. Human Communication, Vol.12, No.2, 215- 229.

Valkenburg, P. M., Peter, J. ,and Schouten, A. P. (2006). Friend Networking Sites And Their Relationship To Adolescents' Well-Being Ands Ocial Self-Esteem. Cyberpsychol \& Behavior, Vol. 9, No.5, 584-590.

Van Dijck, J. (2009). Users Like You? Theorizin Gagency in User-Generated Content. Media. Culture \& Society, Vol. 31, No.1, 41-58.

Wankel, L. and Berger, B. (1990). The Psychological And Social Benefits Of Sport And Physical Activity. Journal of Leisure Research, Vol.22, No.2, 167-182.

Whiting, A. and Williams, D.(2013). Why People Use Social Media: A Uses And Gratifications Approach Article İn Qualitative. Market Research, Vol.16, No.4, 362-368.

Wolfradt, U. and Pretz (2001). Individual Differences In Creativity: Personality, Storywriting, and Hobbies. European Journal of Personality, Vol.15, No.4, 297-310.

Xu, W. W., Park, J. Y., Kim, J. Y. and Park, H. W. (2016). Networked Cultural Diffusion And Creation on YouTube: An analysis of YouTube memes. Journal of Broadcasting \& Electronic Media, Vol.60, No.1, 104-122.

Zhao, W. X., Jiang, J., Weng, J., He, J., Lim, E.-P., Yan, H. and Li, X. (2011). Comparing Twitter and Traditional Media Using Topic Models. In P. Clough, C. Foley, C. Gurrin, G. J. F. Jones, W. Kraaij, H. Lee, ve V. Mudoch (Eds.), Advances In Information Retrieval (pp. 338-349). New York: Springer.

Zuniga, H. G., Die hl, T., Huber, B. and Liu, J. (2017). Personality Traits and Social Media Use in 20 Countries: How Personality Relates to Frequency of Social Media Use, Social Media News Use, and Social Media Use for Social Interaction. Cyberpsychology, Behavior, And Social Networking, Vol. 20, No.9, 540-545.

\section{SUMMARY}

Social media sites are online environments that allow users to create a public profile, share information, create content, and connect with other users 
(INTECO, 2009). These mediums are recognized as an important platform tool for maintaining existing social relationships, getting their latest news, and achieving a large network with relatively little effort (Ghaisani et al., 2017). Most of the individuals produce content such as chat, blogs, photos, videos uploading via social media (Van Dijck, 2009). It is important to know the factors that motivate people to produce this content. Social media sites exhibit wide popularity, high penetration, and an increasing number of features. Considering these features, motivations for using social media are investigated through theoretical frameworks such as the use and satisfaction approach. The use and satisfaction approach used in social media studies provides the first impetus for research in order to know the reasons and motivations of people to use a particular media (Jamal J., 2015). Ruggiero (2000) emphasized that use and satisfaction approach will help researchers to know and learn the importance of mediation communication and the use of various variables to be considered for social media analysis.

Factors such as personality traits, status updates, sharing, sharing photos and videos are closely related to social media site usage behavior (Ryan \& Xenos, 2011; Ong et al., 2011; Moore \& McElroy, 2012; Lee et al., 2014; Fullwood et al. ., 2014). It is very important to understand the reason for people's behavior on social media sites (Li et al., 2019). Individuals use social media to obtain satisfaction such as leisure time, social interaction, information and entertainment (Quan-Haase \& Young, 2010). Satisfaction sought and obtained from a particular environment (motivations) affect the use, frequency and intensity of this environment. Satisfaction gained through the use of social media is shaped by many individual, social, economic, cultural and political factors. Therefore, lower life satisfaction and higher life satisfaction are associated with individuals' motivation to use social media (Papacharissi \& Rubin, 2000).

When the relevant literature is examined, many studies have been found on the motivation of social media use. In these studies, social media motivations and personality and life satisfaction were discussed separately. In this study, unlike other studies, social media use motivations were examined in terms of both personality and life satisfaction by following a holistic approach.

According to the research findings; There is a positive and low level relationship between the adaptive personality trait and the motivations for social interaction, getting information, using leisure time, and economic benefit. Individuals with high compliance characteristics participate more in content shared by others with likes and comments (Choi et al., 2017) and add more friends to their profiles (Ross et al., 2009). This situation expresses the relationship of compatible individuals with their social interaction levels. A study parallel to the findings obtained from Zuniga et al. (2017) and found that individuals with high compliance use social media more frequently and interact with others.

Another research finding has been found to be positively and at a low level relationship between the neuroticism personality trait and social escape, social interaction, getting information, taking leisure time and entertainment motivations. Neurotic individuals are often able to use social media for opportunities to find 
people like themselves or have similar minded people, social support, or learn how to cope with their problems. When the literature is reviewed, there are studies on the relationship between neurotic personality trait and social interaction. One of these studies was conducted by Wolfradt and Doll (2001) and it was found in the study that individuals with high neuroticism show great interest in using the internet for communication when combined with high social interests. At the same time, Swickert et al. (2002) stated that making friendships and making friends are motivating factors in the use of social media for individuals with high neurotic thinking. Kalmus et al. (2011) partially parallels the current study. Kalmus et al. (2011) concluded that individuals who are open to experience and have neurotic thoughts are more likely to use social media for entertainment purposes.

It has been determined in the present study that there is a positive and low level relationship between the personality trait of social media users open to experience and social interaction, information, leisure time and economic benefit. Individuals who are open to experiences frequently use social media and communicate more to share information and give advice (Kalmus et al., 2011). In the present study, while there was a positive and low level relationship between responsibility personality trait and entertainment motivation, a negative and low level relationship was found between motivation to inform. This situation can be interpreted as individuals with higher levels of responsibility are assumed to be more conscious and they may prefer different sources of information in order to obtain information, considering that the time spent on social media is wasted.

It has been determined that there is a positive and low level relationship between the life satisfaction of social media users and their motivation for social interaction, getting information, using leisure time, and economic benefit. There are studies that parallel these results. Baldwin and Tinsley (1998) and Wankel and Berger (1990) stated that participation in leisure activities has a positive correlation with life satisfaction. Lloyd and Auld (2002) stated in their study that increased satisfaction with leisure time and frequency of participation in leisure time activities positively correlated with life satisfaction. TandocJr et al. (2015), stated that, it was concluded that Facebook use reduces depression because it provides communication and socialization.

Another finding obtained from the study is that the personality trait of neuroticism, one of the personality traits of social media users, has a significant effect on social escape motivation, social interaction, information, leisure time and entertainment motivations. This result is based on Amiel and Sargent (2004), Amichai-Hamburger and Vinitzly (2010), Lin et al. (2017) and Kalmus et al. (2011) shows similarities with the findings of the studies.

Additionally, it was concluded that the personality trait of social media users' compatibility, neuroticism and openness to experience had a significant effect on life satisfaction. Finally, in the study, a significant effect of leisure time motivation on satisfaction with life was found. Studies by Baldwin and Tinsley (1998), Wankel and Berger (1990) and Lloyd and Auld (2002) support this finding. 